Article

\title{
Investigation of the Combined Effects of Rising Temperature and Pesticide Contamination on the Swimming Behaviour of Alpine Chironomids
}

\author{
Valeria Lencioni ${ }^{1, * \mathbb{C}}$, Valeria Di Nica ${ }^{2}$ and Sara Villa ${ }^{2} \mathbb{C}$ \\ 1 Section of Invertebrate Zoology and Hydrobiology, MUSE-Museo delle Scienze, Corso del Lavoro e della \\ Scienza 3, 38122 Trento, Italy \\ 2 Department of Earth and Environmental Sciences DISAT, University of Milano Bicocca, Piazza della Scienza 1, \\ 20126 Milan, Italy; dinicavaleria@gmail.com (V.D.N.); sara.villa@unimib.it (S.V.) \\ * Correspondence: valeria.lencioni@muse.it; Tel.: +39-0461270371
}

check for

updates

Citation: Lencioni, V.; Di Nica, V.;

Villa, S. Investigation of the

Combined Effects of Rising

Temperature and Pesticide

Contamination on the Swimming Behaviour of Alpine Chironomids. Water 2021, 13, 3618. https:// doi.org/10.3390/w13243618

Academic Editor:

Nikolaos Skoulikidis

Received: 2 November 2021

Accepted: 14 December 2021

Published: 16 December 2021

Publisher's Note: MDPI stays neutral with regard to jurisdictional claims in published maps and institutional affiliations.

Copyright: (c) 2021 by the authors. Licensee MDPI, Basel, Switzerland. This article is an open access article distributed under the terms and conditions of the Creative Commons Attribution (CC BY) license (https:/ / creativecommons.org/licenses/by/ $4.0 /)$.

\begin{abstract}
Some pollutants can be transported through the atmosphere and travel medium-long distances to be deposited in glaciers at high altitude and latitude. The increase in the rate of glacier melting due to global warming can release these pollutants in alpine streams. This study investigated the combined effects of rising temperatures and chlorpyrifos (CPF) contamination on the swimming behaviour of alpine chironomids collected in a shrinking alpine glacier. We assessed the individual and interaction effects of rising temperatures $\left(2-11^{\circ} \mathrm{C}\right)$ and CPF concentrations $\left(0-110 \mathrm{ng} \mathrm{L}^{-1}\right)$ on the swimming behaviour of Diamesa zernyi (Chironomidae) larvae. Distance $(\mathrm{mm})$ and speed $\left(\mathrm{mm} \mathrm{s}^{-1}\right)$ were recorded using a video-tracking system after 24-72 h of treatment. The two stressors caused different effects on distance and speed, with increasing temperature generally causing hyperactivity and $\mathrm{CPF}$ from hyperactivity to reduced mobility. Two interactions were detected between stressors when combined: (i) CPF superimposed the effect of temperature on both behavioural endpoints i.e., with $110 \mathrm{ng} \mathrm{L}^{-1}$ of $\mathrm{CPF}$, at $11^{\circ} \mathrm{C}$, larvae moved less; (ii) warming $\left(11^{\circ} \mathrm{C}\right)$ magnified the negative effect of CPF: the smallest distance and slowest speed were recorded at the highest values of the two stressors after $72 \mathrm{~h}$. Our results suggest that water contamination by CPF, even at sub-lethal concentrations, might increase the sensitivity of chironomids to warming, and vice versa, raising concerns about freshwater biodiversity conservation under climate change.
\end{abstract}

Keywords: Diamesa zernyi; chlorpyrifos; distance; speed; video tracking; glacier-fed streams; Italian Alps; climate change

\section{Introduction}

The quantity and quality of freshwater is threatened by climate change and pollution [1]. Climate change is leading to the warming of rivers and lakes and shrinking of the glaciers, which in turn is causing a deterioration of melting water quality. This is because glaciers are a temporary sink of inorganic and synthetic organic substances transported from the human settlements in lowlands and mountain valleys to higher altitudes. These pollutants accumulate in the ice and snow due to cold condensation, and are released in melting waters entering the streams [2-7]. Among these are pesticides (such as chlorpyrifos, captan, terbuthylazine), synthetic fragrances (such as galaxolide and tonalide), persistent organic pollutants, and polycyclic aromatic hydrocarbons [7]. Understanding how alpine freshwater species may react and adapt to increasing temperatures and pollutants is a major challenge for hydrobiologists and ecologists that are looking to predict future aquatic biodiversity trends in mountain regions [8,9]. The extent to which highly specialised species living in extreme habitats such as glacier-fed streams are threatened by extinction due to climate change is widely debated [10]. These habitats host simplified animal communities dominated by cold stenothermal chironomids of the genus Diamesa (Diptera Chironomidae), highly specialised to survive freezing, low food availability, and high discharge and 
turbidity [11,12]. Studying the adaptive potential of these species to water heating and pollution of streams fed by shrinking glaciers is a priority for understanding the real risk of extinction of alpine invertebrate species [13-15].

As there is evidence that warming and pesticides can interact synergistically [16,17], we established a laboratory experiment to assess the combined effects of rising temperature and chlorpyrifos (CPF) contamination on the larval behaviour of Diamesa zernyi (Edwards, 1933) as a representative of cryophilous fauna, that are almost restricted to glacierfed streams [18]. Diamesa spp. is not a traditional ecotoxicological model species [19], and no toxicity tests from the OECD Guidelines are available for species belonging to this genus. D. zernyi is a cold stenothermal species, whose larvae have a thermal optimum of $3.7^{\circ} \mathrm{C}[20]$ and are freeze-tolerant (supercooling point $=-6.3^{\circ} \mathrm{C}$; lower lethal temperature $=-16.2^{\circ} \mathrm{C}$ ) [21]. Recent studies have highlighted that, larvae of this, and other Diamesa species, tolerate $96 \mathrm{~h}$ exposure to pharmaceuticals (furosemide, ibuprofen, and trimethoprim), surviving concentrations millions of times higher than those in the environment, but are susceptible to pesticides (CPF, metolachlor, and captan), with significant lethal effects after 24-48 h of exposure [15]. Some authors [22,23] have highlighted that among these pesticides, $\mathrm{CPF}$, at an environmental temperature of $2{ }^{\circ} \mathrm{C}$, affects the swimming behaviour of D. zernyi larvae at LC10,48 $\mathrm{h}\left(1.1 \mu \mathrm{g} \mathrm{L}^{-1}\right)$ and alters their metabolism [24]. However, no information is available on the combined effects of rising temperature and CPF on the behaviour of this species.

We selected swimming behaviour as the endpoint as locomotor performance is an ecologically relevant trait. Recent studies have demonstrated that aquatic organisms can survive when exposed to sub-lethal concentrations of contaminants, but can undergo behavioural changes (e.g., escaping to avoid contamination, changing eating habits, or the mode of locomotion) $[25,26]$. Behavioural disturbances of key species might also affect ecosystem processes [27], for example, by altering prey-predator interactions or competition for food and space $[25,26]$. Changes to behaviour involve an integrated whole-organism response that often incorporates early stress signals produced at the sub-organismal level, including changes to biochemical, cellular, and/or physiological levels $[23,28]$. Sub-lethal endpoints are sensitive to low pollutant concentrations and act as early warning tracers of environmental changes [28-30].

In our study, we experimentally tested the hypothesis that the two stressors interact with each other, affecting the behaviour of $D$. zernyi larvae in a different way than their individual effects. D. zernyi larvae were exposed for $72 \mathrm{~h}$ to different combinations of environmentally relevant concentrations of $\mathrm{CPF}$, selected according to [7,15], and temperatures higher than the environmental temperatures, selected according to [31]. We expected a major effect at the highest temperature and pesticide concentration in a synergistic manner.

\section{Materials and Methods}

\subsection{Test Species}

All laboratory experiments were conducted on the fourth-instar larvae of D. zernyi collected from the Rio Presena stream $\left(46^{\circ} 13.596^{\prime} \mathrm{N} ; 010^{\circ} 34.929^{\prime} \mathrm{E}\right)$ at $2685 \mathrm{~m}$ above sea level. The stream is fed by the Presena glacier (Noce River catchment, Trentino Province, NE Italy).

The larvae were collected with a $30 \mathrm{~cm} \times 30 \mathrm{~cm}$ pond net (mesh size $250 \mu \mathrm{m}$ ) (Scubla $\mathrm{SNC}$, Italy) within $25 \mathrm{~m}$ from the glacier snout, on five occasions in the late summer of $2017(7,11,12,14$, and 18 September 2017). Larvae were gently sorted in the field with tweezers to minimise impact or damage to the larvae, transferred to $100 \mathrm{~mL}$ plastic bottles filled with stream water, and transported to the laboratory in a cooling bag. Species were identified within $24 \mathrm{~h}$ of sampling, and all larvae were checked under a stereomicroscope (MZ 7.5; Leica Microsystems, Wetzlar, Germany; 50×) following [32]. All collected larvae were maintained in $1 \mathrm{~L}$ glass aquaria (approximately 500 larvae/aquarium) with stream water in a thermostatic chamber (ISCO, model FTD250-plus; Teledyne Isco Inc., Lincoln, $\mathrm{NE}$, USA) maintained at $2{ }^{\circ} \mathrm{C}$ with aeration to maintain dissolved oxygen higher than 
$80 \%$ saturation, under a specific photoperiod (8 L:16 D). The incubation temperature $\left(2{ }^{\circ} \mathrm{C}\right)$ was the water temperature measured in the stream using a Hydrolab Quanta (Hydrolab Corporation, Austin, TX, USA) multi-parametric probe at the first sampling date (7 September 2017). To acclimate the larvae to the exposure conditions, randomly selected larvae were transferred $24 \mathrm{~h}$ prior to each experiment to a $500 \mathrm{~mL}$ beaker (approximately 40 larvae/beaker) containing $200 \mathrm{~mL}$ of soft reconstituted water (RW) with the following composition: $4.36 \mathrm{mg} \mathrm{L}^{-1} \mathrm{NaHCO}_{3}, 2.73 \mathrm{mg} \mathrm{L}^{-1} \mathrm{CaSO}_{4} 2 \mathrm{H}_{2} \mathrm{O}, 2.73 \mathrm{mg} \mathrm{L}^{-1} \mathrm{MgSO}_{4}$, and $0.19 \mathrm{mg} \mathrm{L}^{-1} \mathrm{KCl}(\mathrm{pH}=7.7)$ [12]. During acclimation and exposure, the larvae were maintained at $2.0 \pm 0.1^{\circ} \mathrm{C}$ without food, in aerated water.

\subsection{Test Solutions}

The following three CPF concentrations were tested: $1.1,11$, and $110 \mathrm{ng} \mathrm{L}^{-1}$. They correspond to values three, two, and one order of magnitude lower than the LC10,48 h of $1100 \mathrm{ng} \mathrm{L}^{-1}$, estimated at $2{ }^{\circ} \mathrm{C}$ by [15]. Additionally, the intermediate value $\left(11 \mathrm{ng} \mathrm{L}^{-1}\right)$ corresponds to the mean CPF concentration in the Presena stream in summer $\left(9.43 \pm 13.0 \mathrm{ng} \mathrm{L}^{-1}\right)[7]$, comparable with the level of CPF contamination in other Alpine ice melt waters [6]. Each of the CPF (purity $>95 \%$, Sigma Aldrich Laboratories, Milan, Italy) concentrations were prepared in RW and ethanol (analytical purity). Ethanol was added to a final concentration of $<0.1 \mathrm{mg} \mathrm{L}^{-1}$ to favour CPF solubilisation in water. The percentages of co-solvent used in the final test samples was $1.1 \times 10^{-4} \%, 1.1 \times 10^{-5} \%$, and $1.1 \times 10^{-6 \%}$ in volume $(v / v \%)$. These percentages were well below the guidelines suggested by [33] $\left(\leq 0.1 \mathrm{mg} \mathrm{L}^{-1}\right)$ and were tested in order to verify the existence of a co-solvent effect on organism behaviour. Data obtained for the control groups of larvae exposed to the three concentrations of co-solvent ethanol confirmed that there were no effects of ethanol on larval survival and behaviour at $2{ }^{\circ} \mathrm{C}$ without CPF (Tables S1 and S2), validating our experimental design. Given the absence of ethanol effects on survival and behavioural endpoints, in all experiments, the control consisted of RW plus the highest ethanol concentration. The test solutions were renewed every $24 \mathrm{~h}$. The stability of CPF in water has been tested previously [23] at $2{ }^{\circ} \mathrm{C}$ and $72 \mathrm{~h}$ from the addition of $524 \mathrm{ng} \mathrm{L}^{-1}$ of CPF. After $72 \mathrm{~h}$, the CPF concentration was $520 \mathrm{ng} \mathrm{L}^{-1}$. Under such experimental conditions, the nominal concentration of CPF did not change significantly (with a relative standard deviation lower than $20 \%$ among replicates) during the experiments, in accordance with [23].

\subsection{Experimental Procedures}

The control (RW + ET) and test larvae were placed in thermostatic chambers and exposed for $72 \mathrm{~h}$ to three temperatures, $2.0 \pm 0.1,8.0 \pm 0.1$, and $11.0 \pm 0.1^{\circ} \mathrm{C}$. The lowest value $\left(2^{\circ} \mathrm{C}\right)$ corresponded to the mean environmental temperature during the sampling period. The highest value $\left(11^{\circ} \mathrm{C}\right)$ was selected as the mean temperature of glacial streams fed by shrinking glaciers in the same area [12], which is still non-lethal in the short-term $\left(100 \%\right.$ survival was observed after $3 \mathrm{~h}$ at $15^{\circ} \mathrm{C}$ by [31]). The temperature of $11^{\circ} \mathrm{C}$ is higher than the thermal optimum for this species $\left(3.7^{\circ} \mathrm{C}\right.$; [20]). Finally, $8.0^{\circ} \mathrm{C}$ was selected as the intermediate temperature between the other two values. Larval survival was checked every $24 \mathrm{~h}$ during the experiment. For each temperature and CPF concentration, a battery of three replicates, each containing three larvae, were taken. We treated nine organisms for CTRL_ET1, CTRL_ET2, CTRL_ET3, CPF_1.1, CPF_11, and CPF_110 ng L ${ }^{-1}$ at each temperature of exposure (Figure 1). Thus, we treated 54 organisms for all treatments at each exposure temperature, with a total of 162 organisms ( 54 organisms $\times 3$ temperatures). Every $24 \mathrm{~h}$, three repeated measurements were recorded using a video-based tracking system in groups of three larvae at a time (up to nine larvae) in a beaker filled with the same exposure medium. After recording, the larvae were placed back in the glass vessels used for the exposure. Finally, 27 measurements were taken for each treatment (i.e., each combination of chemical/control plus temperature of exposure). All treatments, each with the respective control, were conducted simultaneously in a single experiment for $72 \mathrm{~h}$. For each temperature, a battery of nine replicates with $\mathrm{CPF}(3 \times$ each concentration) and 
three control replicates, with three larvae each, were used. Every $24 \mathrm{~h}$, a sub-group of one to three larvae (only live larvae were considered) was taken from each replicate and tested. Three repeated measurements were recorded for each larva using a video-based tracking system.

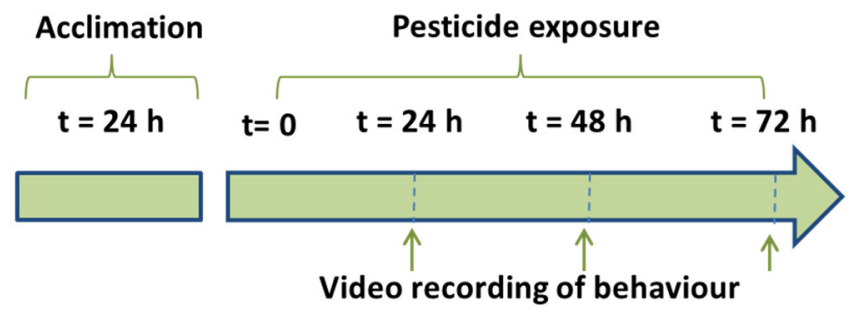

\section{Thermal conditions}

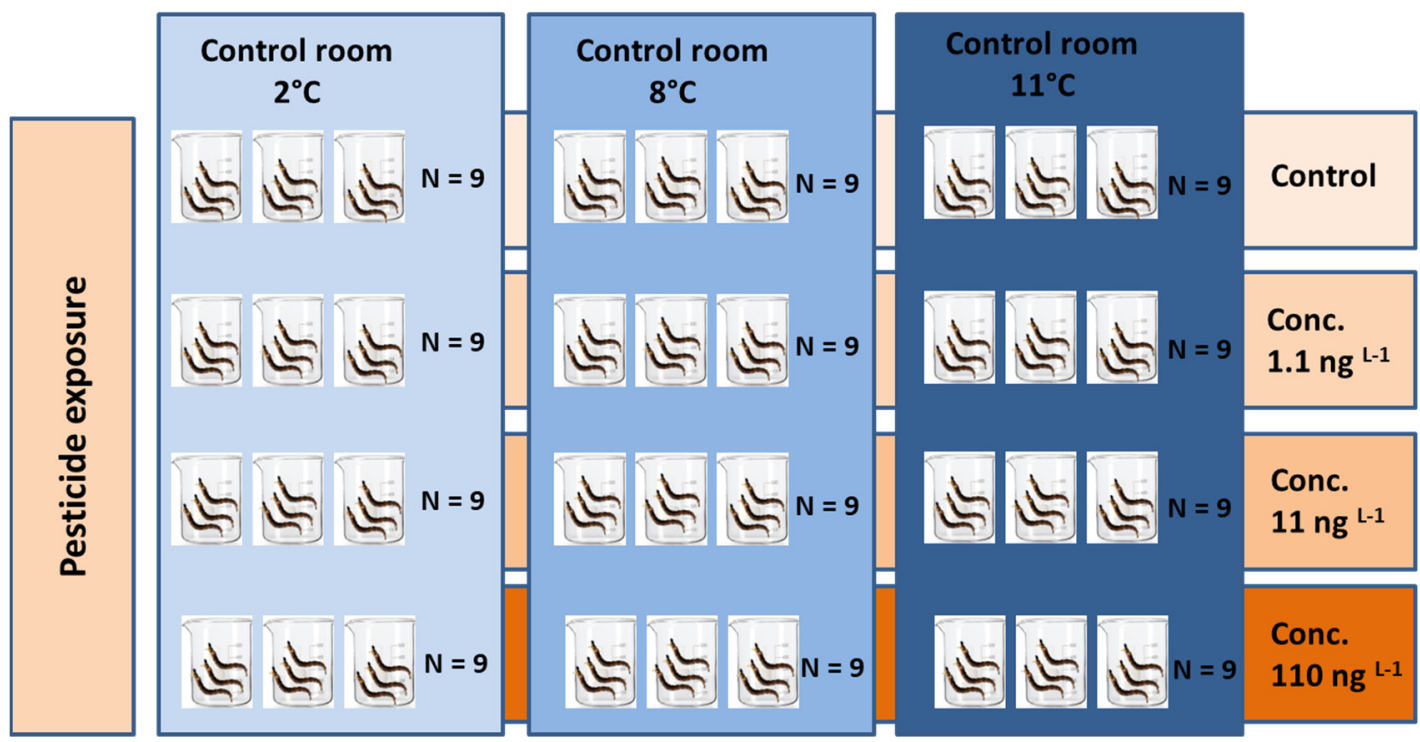

Figure 1. The experimental design.

Video footage was taken after 24,48 , and $72 \mathrm{~h}$ of exposure under different combinations of temperature and pesticide concentration to monitor the time effect on behaviour. A prolonged exposure time of up to $72 \mathrm{~h}$ in comparison to standardised test protocols (up to $48 \mathrm{~h}$ ) [22] was considered as it is known that in cold-adapted organisms, the expression of toxicity is delayed owing to slow CPF uptake kinetics and a slow metabolic rate [34]. Furthermore, data on behaviour were recorded every $24 \mathrm{~h}$ for 3 days as contamination is sometimes characterised by short-term peak concentrations, such as when pesticides are applied to crops $[35,36]$. CPF has a high value of Kow (octanol/water partition coefficient, $\operatorname{logKow}=4.7$, according to the PPDB: Pesticide Properties DataBase), which may be responsible for its delayed passage through the cell membrane [37].

All videos were recorded for $180 \mathrm{~s}$ at high resolution $(1920 \times 1080$ pixels $)$ using a digital high-definition camera (Raspberry Pi 3 with Camera Module v2) positioned $10 \mathrm{~cm}$ from the bottom of each beaker. During this time, the water temperature varied between +0.1 to $+0.3^{\circ} \mathrm{C}$, as recorded using a portable thermometer (Koch $13211 ; \pm 1{ }^{\circ} \mathrm{C}$ ). Behavioural effects were assessed.

Video processing and analysis were conducted using the FFmpeg (900 frames; 30 frames per second) (http: / / www.ffmpeg.org (accessed on 21 September 2017)) and ImageJ software (http: / /imagej.nih.gov/ij/ (accessed on 21 September 2017)), respectively, following $[19,22]$. The software was optimized/calibrated according to [19] to monitor the distance and average speed of the (the behavioural endpoints) of the Diamesa larvae. Data 
on distance and speed were converted from pixels to $\mathrm{mm}$ and from pixels s ${ }^{-1}$ to $\mathrm{mm} \mathrm{s}^{-1}$, respectively, according to the procedure described in [22]. An example is given in Video S1 ("Diamesa zernyi swimming").

\subsection{Statistical Analysis}

The normality and homogeneity of variances were tested using the KolmogorovSmirnov and Leven's tests, respectively. Distance and speed were normally distribution (K-S $p<0.05)$, and survival proportion data were normalised (arcsine-square-roottransformation) following [38]. Statistically significant effects of temperature and CPF on larval survival and behaviour after the three different exposure periods were investigated using two-way analysis of variance (ANOVA). The results of each treatment group were compared with those of the control group and treatment level differences using Dunnett's multiple comparisons test. The data shown in Figures A2-A4 were normalised by setting the untreated control group (untreated larvae) as 1.

Statistical analyses were conducted using GraphPad Prism 6 (version 6.01; 2012), SPSS 24 (IBM), and STATISTICA (version 12.0; 2013 @ StatSoft Inc., Tulsa, OK, USA).

\section{Results}

\subsection{Survival under Thermal Stress and CPF Exposure}

Without $\mathrm{CPF}$, larvae were found to be alive after $24 \mathrm{~h}$, independent of temperature (Table 1 and Table S3), and within the acceptable range $\leq 15 \%$ set by the OECD guideline n. 235, that refers to the Chironomus spp. [39], throughout the test duration at the optimal thermal regime of $2{ }^{\circ} \mathrm{C}$. Increased mortality was recorded with increasing the time of exposure and at higher temperatures, for example, after $72 \mathrm{~h}$ at 8 and $11^{\circ} \mathrm{C}$.

Table 1. Mean ( \pm standard error) percent survival of the Diamesa zernyi larvae exposed to increasing temperatures $\left(2,8\right.$, and $\left.11^{\circ} \mathrm{C}\right)$ and chlorpyrifos $(\mathrm{CPF})$ concentrations $\left(0,1.1,11\right.$, and $\left.110 \mathrm{ng} \mathrm{L}^{-1}\right)$, for 24,48 , and $72 \mathrm{~h}$.

\begin{tabular}{|c|c|c|c|}
\hline & CTRL $2{ }^{\circ} \mathrm{C}$ & CTRL $8{ }^{\circ} \mathrm{C}$ & CTRL $11^{\circ} \mathrm{C}$ \\
\hline $24 \mathrm{~h}$ & $100 \pm 0.0$ & $100 \pm 0.0$ & $100 \pm 0.0$ \\
\hline $48 \mathrm{~h}$ & $100 \pm 0.0$ & $89 \pm 11$ & $67 \pm 17$ \\
\hline $72 \mathrm{~h}$ & $89 \pm 9$ & $78 \pm 15$ & $56 \pm 17$ \\
\hline \multicolumn{4}{|c|}{$\mathrm{CPF}\left(2^{\circ} \mathrm{C}\right)$} \\
\hline & 1.1 & 11 & 110 \\
\hline $24 \mathrm{~h}$ & $100 \pm 0.0$ & $100 \pm 0.0$ & $100 \pm 0.0$ \\
\hline $48 \mathrm{~h}$ & $100 \pm 0.0$ & $89 \pm 11$ & $89 \pm 11$ \\
\hline $72 \mathrm{~h}$ & $100 \pm 0.0$ & $44 \pm 18$ & $56 \pm 18$ \\
\hline \multicolumn{4}{|c|}{$\mathrm{CPF}\left(8^{\circ} \mathrm{C}\right)$} \\
\hline & 1.1 & 11 & 110 \\
\hline $24 \mathrm{~h}$ & $100 \pm 0.0$ & $100 \pm 0.0$ & $100 \pm 0.0$ \\
\hline $48 \mathrm{~h}$ & $100 \pm 0.0$ & $89 \pm 11$ & $100 \pm 0.0$ \\
\hline $72 \mathrm{~h}$ & $89 \pm 11$ & $78.0 \pm 15$ & $100 \pm 0.0$ \\
\hline \multicolumn{4}{|c|}{$\mathrm{CPF}\left(11^{\circ} \mathrm{C}\right)$} \\
\hline & 1.1 & 11 & 110 \\
\hline $24 \mathrm{~h}$ & $100 \pm 0.0$ & $100 \pm 0.0$ & $100 \pm 0.0$ \\
\hline $48 \mathrm{~h}$ & $100 \pm 0.0$ & $78.0 \pm 15$ & $67 \pm 17$ \\
\hline $72 \mathrm{~h}$ & $100 \pm 0.0$ & $67 \pm 17$ & $44 \pm 18$ \\
\hline
\end{tabular}

The addition of $\mathrm{CPF}$ at $2{ }^{\circ} \mathrm{C}$ caused significant mortality ( $\left.>15 \%\right)$ at concentrations of 11 (survival $=44 \pm 18 \%$ ) and 110 (survival $=56 \pm 18 \%$ ) ng L ${ }^{-1}$ after $72 \mathrm{~h}$. The highest mortality $(44 \pm 18 \%)$ was observed after $72 \mathrm{~h}$ at $11^{\circ} \mathrm{C}$ and $110 \mathrm{ng} \mathrm{L}^{-1}$.

Survival values recorded after $72 \mathrm{~h}$ at the intermediate and highest CPF concentrations were outside the acceptable limit of mortality set by the OECD guidelines [33]. Despite 
this, behaviour of the surviving larvae was analysed under these experimental conditions to add information on the stress response at the individual level at concentrations and temperatures to identify the upper surviving limits for this species. As the surviving larvae were not found moribund, we considered valid results on behaviour even under such experimental conditions.

\subsection{Behaviour under Thermal Stress and CPF Exposure}

Without $\mathrm{CPF}$, distance and speed increased with respect to the control $\left(2^{\circ} \mathrm{C}\right)$ after only $24 \mathrm{~h}$ of exposure (Figure A1). For distance, this increase was significant between 2 and $8{ }^{\circ} \mathrm{C}$ at $24 \mathrm{~h}$, and between 2 and $11^{\circ} \mathrm{C}$ and 8 and $11^{\circ} \mathrm{C}$ at $72 \mathrm{~h}$ of exposure (Figures A1A and 2). The increase in speed was significant between 2 and $11^{\circ} \mathrm{C}$ at $24 \mathrm{~h}$, between 8 and $11^{\circ} \mathrm{C}$ at $48 \mathrm{~h}$, and between 2 and $11^{\circ} \mathrm{C}$ and 8 and $11^{\circ} \mathrm{C}$ at $72 \mathrm{~h}$ of exposure (Figure A1B). Overall, higher values of distance and speed (independent of temperature) were observed at $24 \mathrm{~h}$ (both) and $48 \mathrm{~h}$ (only speed).

$$
\text { CPF }=0 \mathrm{ng} \mathrm{L}^{-1}
$$
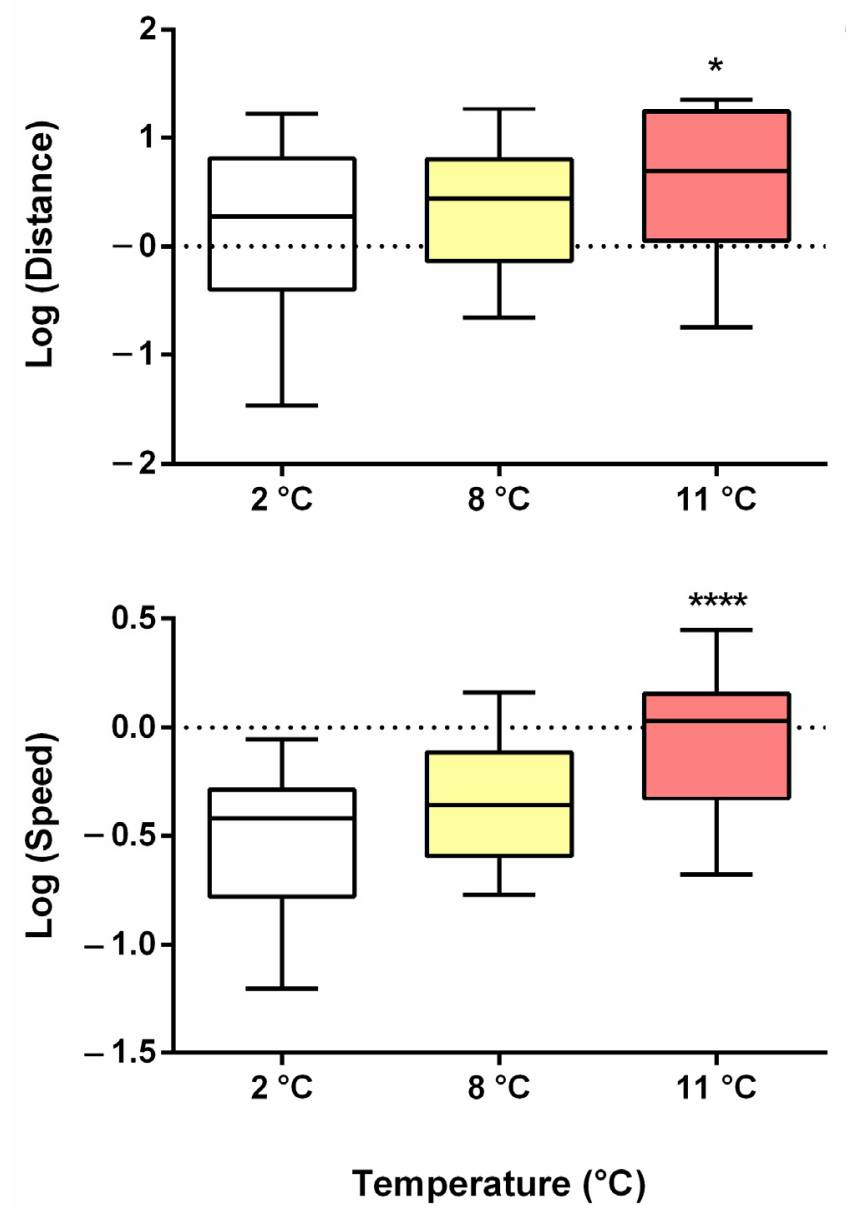

Figure 2. Boxplots of the log-transformed median distance (up) and speed (down) under increasing thermal stress after $72 \mathrm{~h}$ of treatment. Asterisks = significant differences from the control group ${ }^{*} p<0.05 ;{ }^{* * * *} p<0.0001$.

The addition of $\mathrm{CPF}$ at $2{ }^{\circ} \mathrm{C}$ caused a significant negative effect only on speed after $72 \mathrm{~h}$ of exposure at the highest concentration $\left(110 \mathrm{ng} \mathrm{L}^{-1}\right.$ ) (Figures A2B and 3). 


\section{$2{ }^{\circ} \mathrm{C}$}

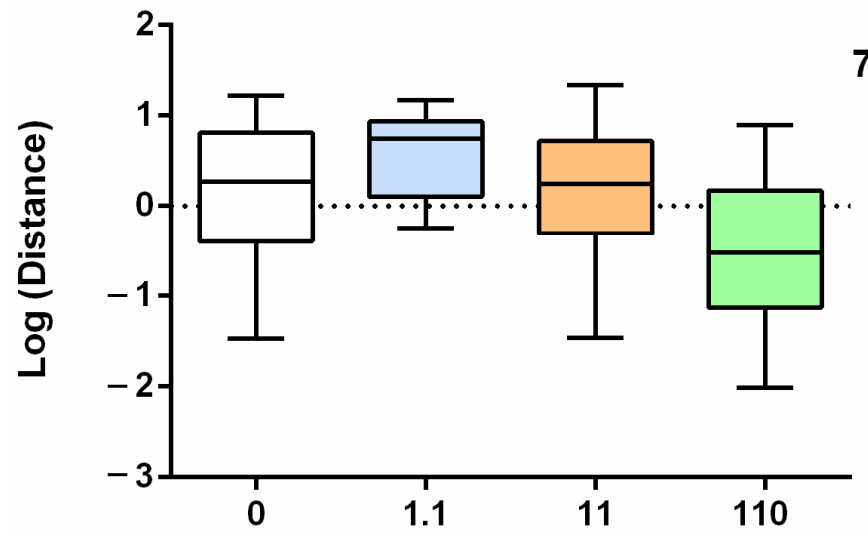

$72 \mathrm{~h}$

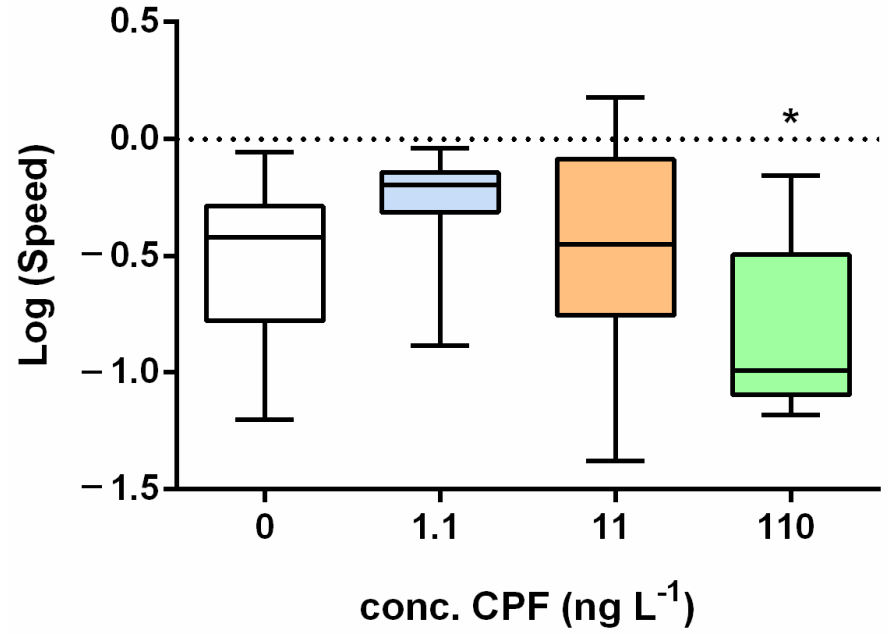

Figure 3. Boxplots of the log-transformed median distance (up) and speed (down) under an increasing chemical stress after $72 \mathrm{~h}$ of treatment. Asterisks = significant differences from the control group $* p<0.05$

Under multiple stresses (Figures A3 and A4) after $24 \mathrm{~h}$, significant effects were observed only on speed and were higher after $24 \mathrm{~h}$ at $8^{\circ} \mathrm{C}$ with $1.1 \mathrm{ng} \mathrm{L}-1$. At $11^{\circ} \mathrm{C}$, speed was lower than that at $8^{\circ} \mathrm{C}$, with the lowest $\mathrm{CPF}$ concentration (Figure A4A). After 48 and $72 \mathrm{~h}$ of exposure, significant positive and negative effects were detected, respectively, for distance and speed. After $48 \mathrm{~h}$, the distance generally increased at $1{ }^{\circ} \mathrm{C}$ with $11 \mathrm{ng} \mathrm{L}^{-1}$ and at $8^{\circ} \mathrm{C}$ with $110 \mathrm{ng} \mathrm{L}^{-1}$ (Figure A3B). A similar trend was observed for speed, which was higher than in the control with $11 \mathrm{ng} \mathrm{L}^{-1}$ at 8 and $11^{\circ} \mathrm{C}$ and with $110 \mathrm{ng} \mathrm{L}^{-1}$ at $8{ }^{\circ} \mathrm{C}$ (Figure A4B). After $72 \mathrm{~h}$ (Figure 4), the most evident change was the reduction in distance (Figure $\mathrm{A} 3 \mathrm{C}$ ) and speed (Figure $\mathrm{A} 4 \mathrm{C}$ ) at $11^{\circ} \mathrm{C}$ with $110 \mathrm{ng} \mathrm{L}^{-1}$ of CPF. 


\section{$72 \mathrm{~h}$}
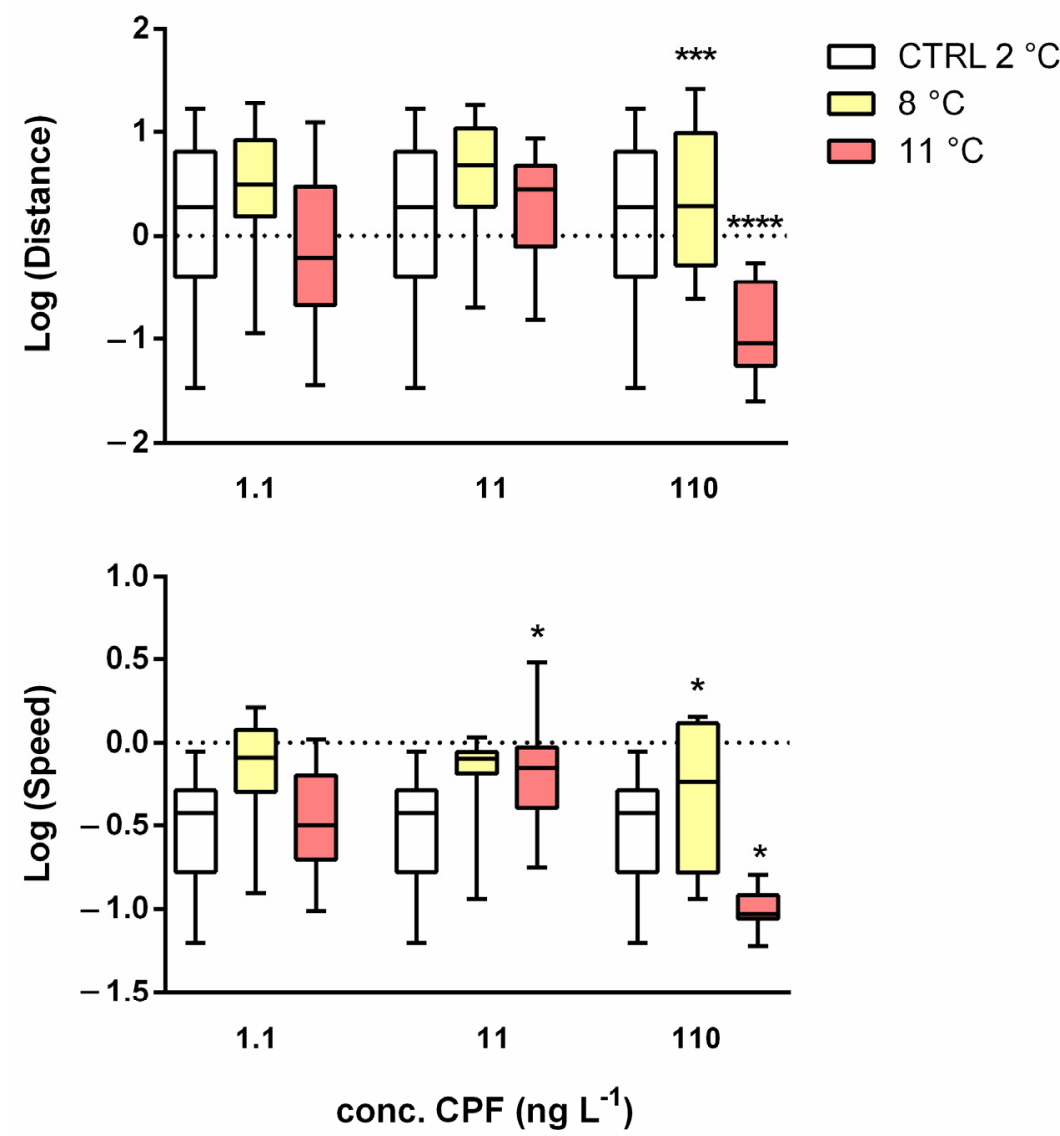

Figure 4. Boxplots of the log-transformed median distance (up) speed (down) variable against concentration and temperatures after $72 \mathrm{~h}$ of treatment. Asterisks $=$ significant differences from the control group * $p<0.05 ;{ }^{* * *} p<0.001 ;{ }^{* * * *} p<0.0001$.

\section{Discussion}

Hydrological alterations, habitat degradation and loss, pollution, overexploitation, invasive species, and climate change have been detected as major threats to freshwater ecosystems [40]. Each category includes multiple stressors to biodiversity that interact, often with effects greater than (synergism), less than (antagonism), or equal to the sum of their individual effects [41,42]. Scientists have sought to identify the most significant causes of stress, understand and predict the responses of species and communities to individual and multiplestressor configurations [43,44], support administrations in developing sustainable management actions, and finding nature-based solutions according to the 2030 Agenda for Sustainable Development (https:/ / www.un.org/sustainabledevelopment/development-agenda/ (accessed on 5 September 2021)). The results of our study are relevant in this context, highlighting, for the first time, the interaction between the two stressors (global warming, and chemical pollution) on biodiversity in remote alpine areas. To predict the impact of pesticides under global warming, we need to understand how species respond to the interaction between the two stressors and whether their sensitivity to increasing temperature can be influenced by chemical stressors and vice versa [45]. This is the first time that temperature and chemical stress interactions have been experimentally tested using wild insect species from glacier-fed streams.

Temperature and CPF separately also affected survival. In particular, at $11^{\circ} \mathrm{C}, \mathrm{CPF}$ concentrations of 11 and $110 \mathrm{ng} \mathrm{L}^{-1}$ had detrimental effects on larval survival. Unlike what was observed for shorter periods of exposure time $[15,31]$, at $11^{\circ} \mathrm{C}$, the concentrations of CPF at $1 / 100$ to $1 / 10$ of the LC10,48 $\mathrm{h}$ were not sub-lethal even after prolonged exposure (72 h). Between 24 and $48 \mathrm{~h}$ of exposure, survival remained $\geq 89 \%$ between CPF concen- 
trations of 0 and $110 \mathrm{ng} \mathrm{L}^{-1}$, which is within the acceptable criteria for chironomids [39], confirming these as sub-lethal values within $48 \mathrm{~h}$ of exposure. This evidence supports [34] the delayed toxicity of CPF, particularly for organisms from cold freshwater. This is relevant for Diamesa species under the continuous release of pesticides from the glacier during the melting season $[7,36]$, corresponding to their biological window [20].

Under the two stressors, at the highest temperature $\left(11^{\circ} \mathrm{C}\right)$ and concentration $\left(110 \mathrm{ng} \mathrm{L}^{-1}\right)$, survival after $72 \mathrm{~h}$ was comparable to that under the two stressors separately. These results suggest that chemical and thermal stresses do not have an additive effect on survival, as the mortality registered under both stress conditions at 48 or $72 \mathrm{~h}$ were only slightly higher than those observed under a single stress.

Regarding behaviour, temperature had a positive effect on both endpoints, obtaining almost double the values of the control at $11^{\circ} \mathrm{C}$ than at $2{ }^{\circ} \mathrm{C}$ independently of the time of exposure. In ectotherms, basal metabolism (i.e., oxygen consumption) increases at temperatures higher than the range in which the species normally lives [46], which could justify the hyperactivity of the larvae. Considering that significant mortality occurred after $72 \mathrm{~h}$ at $11^{\circ} \mathrm{C}$, this might be considered as the temperature near the upper limits of thermal tolerance. Near this limit, oxygen is typically limiting, affecting all higher biological functions (i.e., muscular activity, growth, and reproduction), thereby affecting survival and, at long-term, the fate of species [47].

The addition of $\mathrm{CPF}$ to larvae kept at $2{ }^{\circ} \mathrm{C}$ did not show any effects, with the sole exception of a significant decrease in speed after $72 \mathrm{~h}$ at $110 \mathrm{ng} \mathrm{L}^{-1}$. This suggests that at $2{ }^{\circ} \mathrm{C}, \mathrm{CPF}$ does not affect larval behaviour in the short term.

Under multiple stresses, hyperactivity and immobility were observed at different times of exposure, highlighting the interactions between the two stressors in a different way in terms of distance and speed. Speed was the first to show a change in the endpoint. In the short term $(24 \mathrm{~h})$, we observed only an increase in speed, at $8{ }^{\circ} \mathrm{C}$, in the presence of $1.1 \mathrm{ng} \mathrm{L}^{-1} \mathrm{CPF}$. This could be caused by tremors in the larvae, which suggested an initial state suffering. After $48 \mathrm{~h}$, we observed an increase in both distance and speed with concentrations $\geq 11 \mathrm{ng} \mathrm{L}^{-1}$, particularly at $8{ }^{\circ} \mathrm{C}$ (at $11^{\circ} \mathrm{C}$ only with an intermediate concentration of $11 \mathrm{ng} \mathrm{L}^{-1}$ ). Hyperactivity is de facto an escape reaction (avoidance). It can be an adaptive response to avoid stress conditions [48] associated with low-dose stimulation and high-dose inhibition [49]. Larvae might move to find refuge in the hyporheic zone. In fact, a consistent number of studies have suggested that, in all streams, the hyporheic zone is used by benthic invertebrates as a refuge during floods, droughts, or other stressful conditions $[50,51]$. The strongest effect of the combination of high temperature $\left(11^{\circ} \mathrm{C}\right)$ and high CPF concentration ( $\left.110 \mathrm{ng} \mathrm{L}^{-1}\right)$ was evident after three days of treatment, with a significant decrease in both distance and speed. The immobilisation of the larvae was probably due to the neurotoxicity of $\mathrm{CPF}$, which inhibits the enzyme acetylcholinesterase, interfering with neural transmission [52-54].

Summarizing, these results verified our hypothesis, emphasising two interactions between the two types of stress. First, CPF superimposed the effect of temperature on both behaviour endpoints, i.e., without $\mathrm{CPF}$, larvae moved faster at higher temperatures but with the pesticide, larvae moved less even at very low concentrations and at $11^{\circ} \mathrm{C}$. Second, warming $\left(11^{\circ} \mathrm{C}\right)$ magnified the negative effect of the toxicant $[17,55]$. The lowest values for both endpoints were recorded under maximum values of both the stressors (Video S1 "Diamesa zernyi swimming"). In such conditions, the basal metabolism of the larvae was probably reduced and, consequently, no attempt to escape was observed. We might argue that organisms devote energy in developing a detoxification response in a physiological state of stress $[15,19,22-24,56]$. CPF and other organophosphate insecticides are known to exhibit increased toxicity in invertebrates at elevated temperatures [57,58], with effects on survival and behaviour (e.g., altering the escaping speed of the prey of damselflies even at concentrations that current legislation considers environmentally protective [59]).

Additionally, warming influences CPF uptake in aquatic insects [60], increasing its permeability across cell membranes, promoting a higher uptake, and activating a detox- 
ification response [34]. Our study emphasised that warming changes the impact of CPF (i.e., magnifying the negative effect) on behaviour and $\mathrm{CPF}$ changes the species sensitivity to warming (i.e., inverting the effect on behaviour), indicating that global warming may magnify the impact of pesticides [16,17]. A temperature higher than the thermal ecological optimum, without the insecticide, altered the behaviour of $D$. zernyi larvae, increasing the movement likely related to increasing basal metabolism [14]. When high, but not lethal, temperature was combined with high but sub-lethal concentrations of $\mathrm{CPF}$, higher temperatures seem to strengthen the negative effect of the contaminants on behaviour, making it more bioavailable [61].

Some authors [62] have reported that increased energy demand for maintenance of basal metabolism that is not met by increased generation of energy is central to the stress effects caused by temperature and pollutants. Therefore, there is a likely physiological mechanism underlying how pollutants shape thermal tolerance. Evidence of pesticideinduced climate change sensitivity and warming-induced pesticide change sensitivity has been observed in eurythermal dragonflies [17], but with warming reducing the negative effect of pesticides on sensitivity (these experiments were conducted at $20-24{ }^{\circ} \mathrm{C}$, at which the degradation rate of pesticide is higher than that at our experimental temperature range).

\section{Conclusions}

In 2020, the European Commission formally adopted regulations proposing not to renew the approvals of the insecticides CPF and CPF-methyl (https:/ / ec.europa.eu/food/ plants/pesticides/approval-active-substances/renewal-approval/chlorpyrifos-chlorpyrifosmethyl_en (accessed on 21 September 2021)). Despite this, these results remain of interest because, according to their persistence observed for other POPs and banned pesticides, CPF will continue to be detected in the environment for several years, similar to endosulfan [63]. In addition, these findings may be valid for other lipophilic and semi-volatile toxicants that may be found in remote areas, such as the synthetic fragrances or the polycyclic aromatic hydrocarbons $[7,64]$. This study emphasises the importance of considering effects on behaviour (e.g., swimming speed) in early detection of the adverse effects of any stressor in toxicology evaluations and the incipient need to use wild alpine species for the evaluation of natural ecosystems to increase the ecological realism of ex situ experiments. However, a major limitation is that working on ecotoxicological non-model species, without standard experimental guidelines, and which are difficult to rear in the laboratory and are at a risk of extinction, is quite challenging [10].

Future research is needed to detect the long-term and/or indirect effects of organic pollutants, under continuous and prolonged exposure, on different levels of biological organisation to further increase ecological realism of ecotoxicological studies. 'Omics' technologies, as adapted from previous ecotoxicology protocols (e.g., [65]), could be employed to further study the physiological effects of these pollutants.

Supplementary Materials: The following are available online at https:/ /www.mdpi.com/article/10 $.3390 / w 13243618 / s 1$, Table S1: Effect of ethanol on survival, distance and speed in control groups, Table S2: Mean survival, distance and speed of Diamesa zernyi larvae exposed at $2{ }^{\circ} \mathrm{C}$ to three ethanol concentrations, Table S3: Mean survival, distance and speed of Diamesa zernyi larvae exposed to 2, 8 and $11^{\circ} \mathrm{C}$ in solution with four different chlorpyrifos concentrations (Conc $=0,1.1,11,110 \mathrm{ng} \mathrm{L}^{-1}$ ), after 24, 48 and $72 \mathrm{~h}$. Video S1: Effects of CPF on Diamesa zernyi swimming behaviour.

Author Contributions: Conceptualisation, V.L. and S.V.; methodology, V.L. and S.V.; software, V.D.N.; formal analysis, V.D.N.; investigation, V.D.N.; resources, V.L.; data curation, V.L. and V.D.N.; writingoriginal draft preparation, V.L.; writing-review and editing, V.L. and S.V.; visualization, V.D.N.; supervision, V.L. and S.V.; project administration, V.L.; funding acquisition, V.L. All authors have read and agreed to the published version of the manuscript.

Funding: This research was funded by the Cassa di Risparmio di Trento e Rovereto Foundation (CARITRO n. Rif. Int.: 2015.0199; 2015-2018), the MUSE and the University of Milano-Bicocca. 
Data Availability Statement: The data presented in this study are available on request from the corresponding author. The data are not publicly available because of jointed property with the foundation that financed the project.

Acknowledgments: We are grateful to Alessandra Franceschini, Francesca Paoli and Francesco Bellamoli (MUSE) for their help with the field and laboratory work and to Filippo Menolli (MUSE) for the editing of the Video S1 "Diamesa zernyi swimming".

Conflicts of Interest: The authors declare no conflict of interest. The founder CARITRO had no role in the design of the study; in the collection, analyses, or interpretation of data; in the writing of the manuscript, or in the decision to publish the results.

\section{Appendix A}

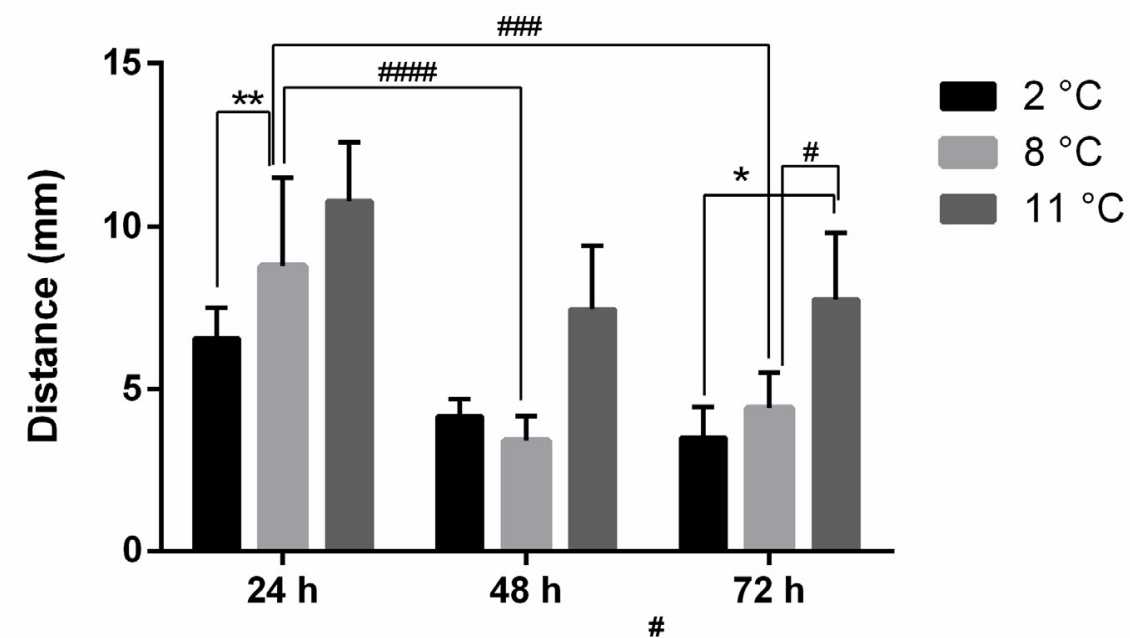

(A)

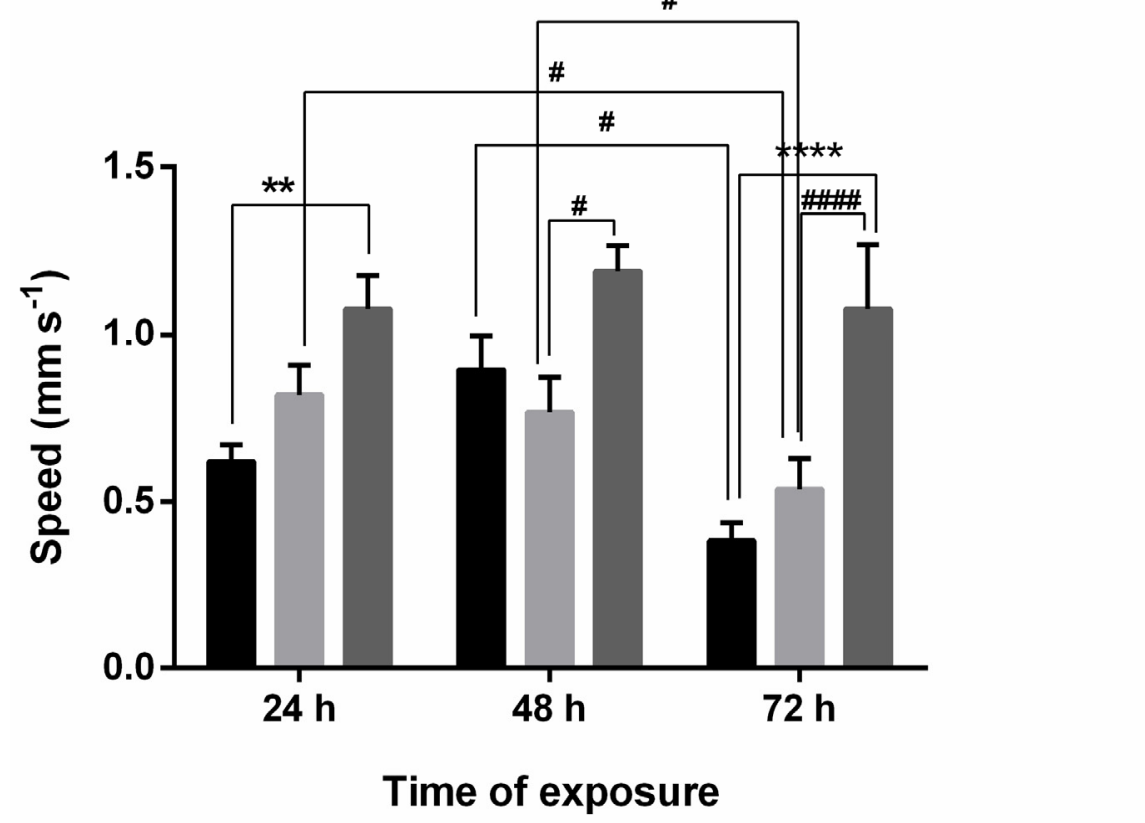

(B)

Figure A1. Distance $(\mathrm{mm})(\mathbf{A})$ and speed $\left(\mathrm{mm} \mathrm{s}^{-1}\right)(\mathbf{B})$ of larvae under thermal stress $\left(8\right.$ and $\left.11^{\circ} \mathrm{C}\right)$ after 24, 48, and $72 \mathrm{~h}$. Asterisks = significant differences from the control group ${ }^{*} p<0.05 ;{ }^{* *} p<0.01$; $* * * * p<0.0001$. Significant differences among samples exposed to different concentrations ${ }^{\#} p<0.05$; \#\#\# $p<0.001$; \#\#\# $p<0.0001$. 
$2{ }^{\circ} \mathrm{C}$

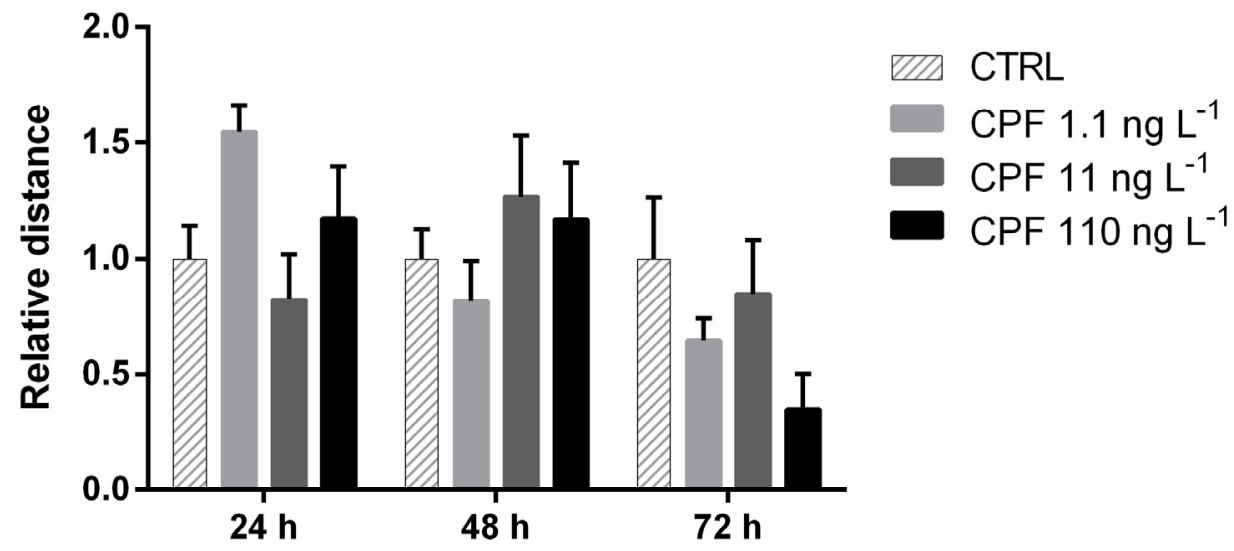

(A)

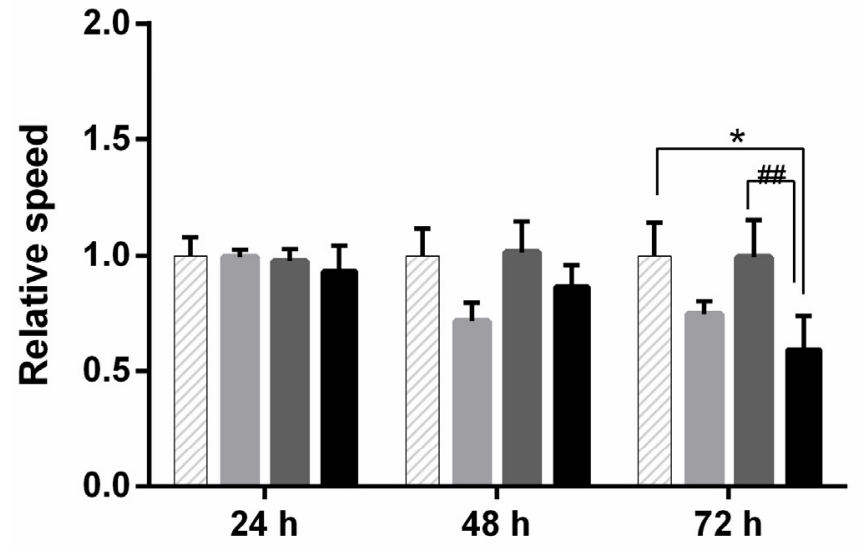

(B)

Time of exposure

Figure A2. Relative distance (A) and speed (B) of larvae under chemical stress (at $2{ }^{\circ} \mathrm{C}$ ) after 24,48 , and $72 \mathrm{~h}$ of exposure to chlorpyrifos $\left(\mathrm{CPF}=1.1,11\right.$ and $\left.110 \mathrm{ng} \mathrm{L}^{-1}\right)$. Distance values were normalized on the CTRL set equal to 1 . Data are Asterisks = significant differences from the control group ${ }^{*} p<0.05$. Significant differences among samples exposed to different concentrations ${ }^{\# \#} p<0.01$.

$24 \mathrm{~h}$

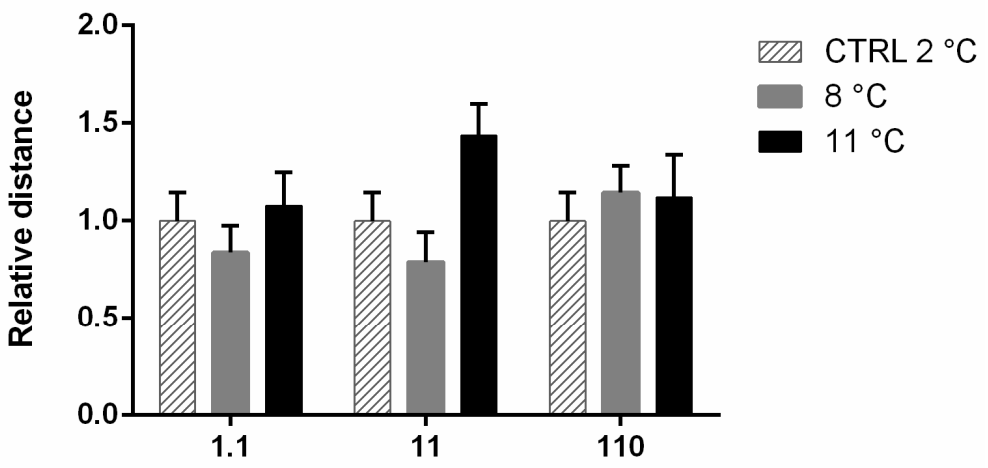

Figure A3. Cont. 


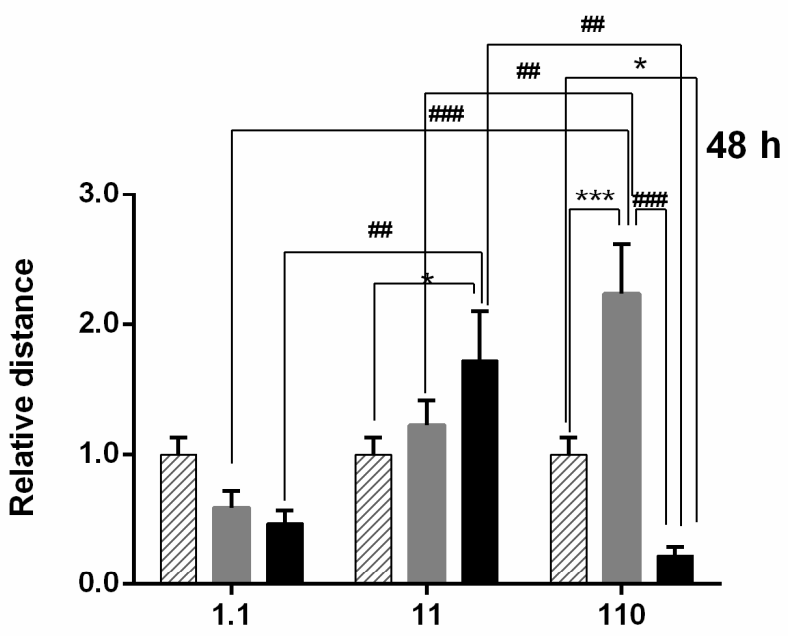

(B)

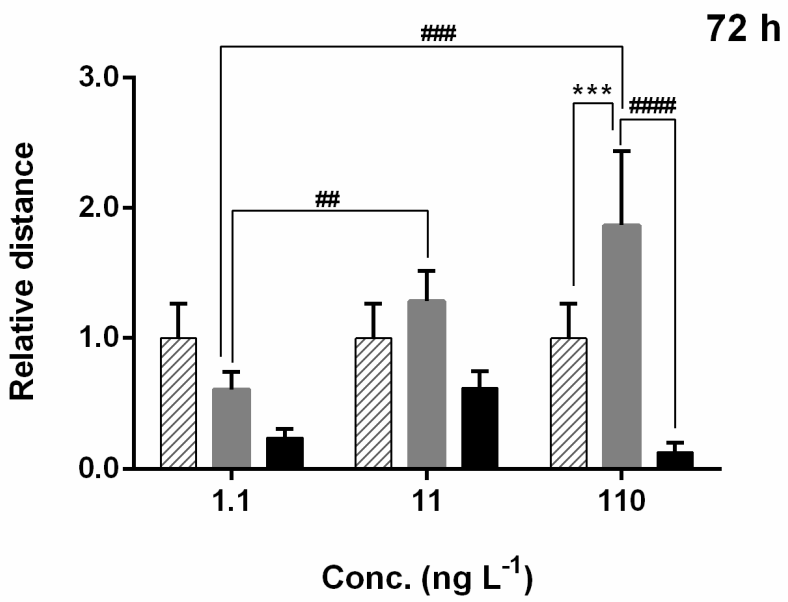

(C)

Figure A3. Relative distance of larvae under combined thermal stress ( 8 and $11^{\circ} \mathrm{C}$ ) and chemical stress with chlorpyrifos (CPF $=1.1,11$ and $110 \mathrm{ng} \mathrm{L}{ }^{-1}$ ) after $24 \mathrm{~h}(\mathbf{A}), 48 \mathrm{~h}(\mathbf{B})$, and $72 \mathrm{~h}(\mathbf{C})$. Asterisks $=$ significant differences from the control group set equal to $1 .{ }^{*} p<0.05 ;{ }^{* * *} p<0.001$. Significant differences among samples exposed to different concentrations ${ }^{\# \#} p<0.01$; \#\# $p<0.001$; \#\#\#\# $p<0.0001$.

\section{$24 \mathrm{~h}$}

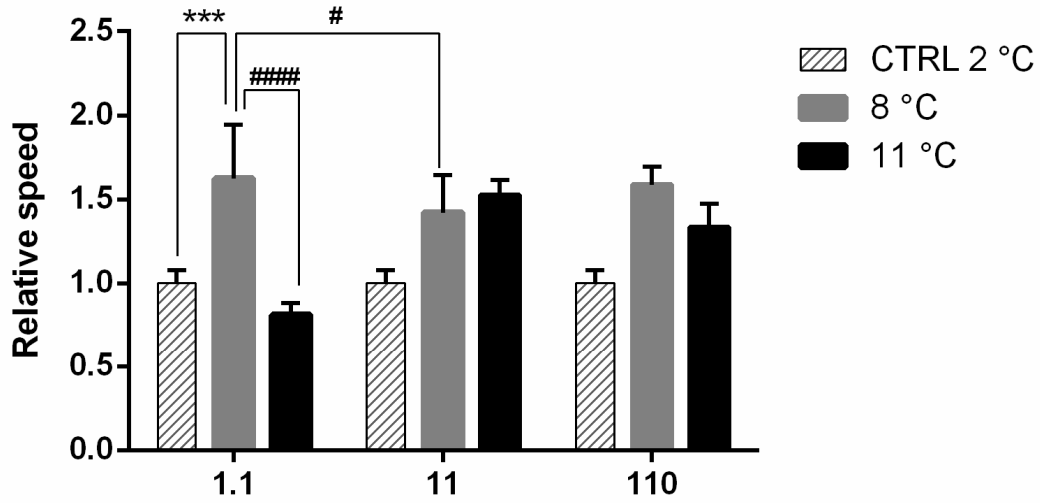

(A)

Figure A4. Cont. 

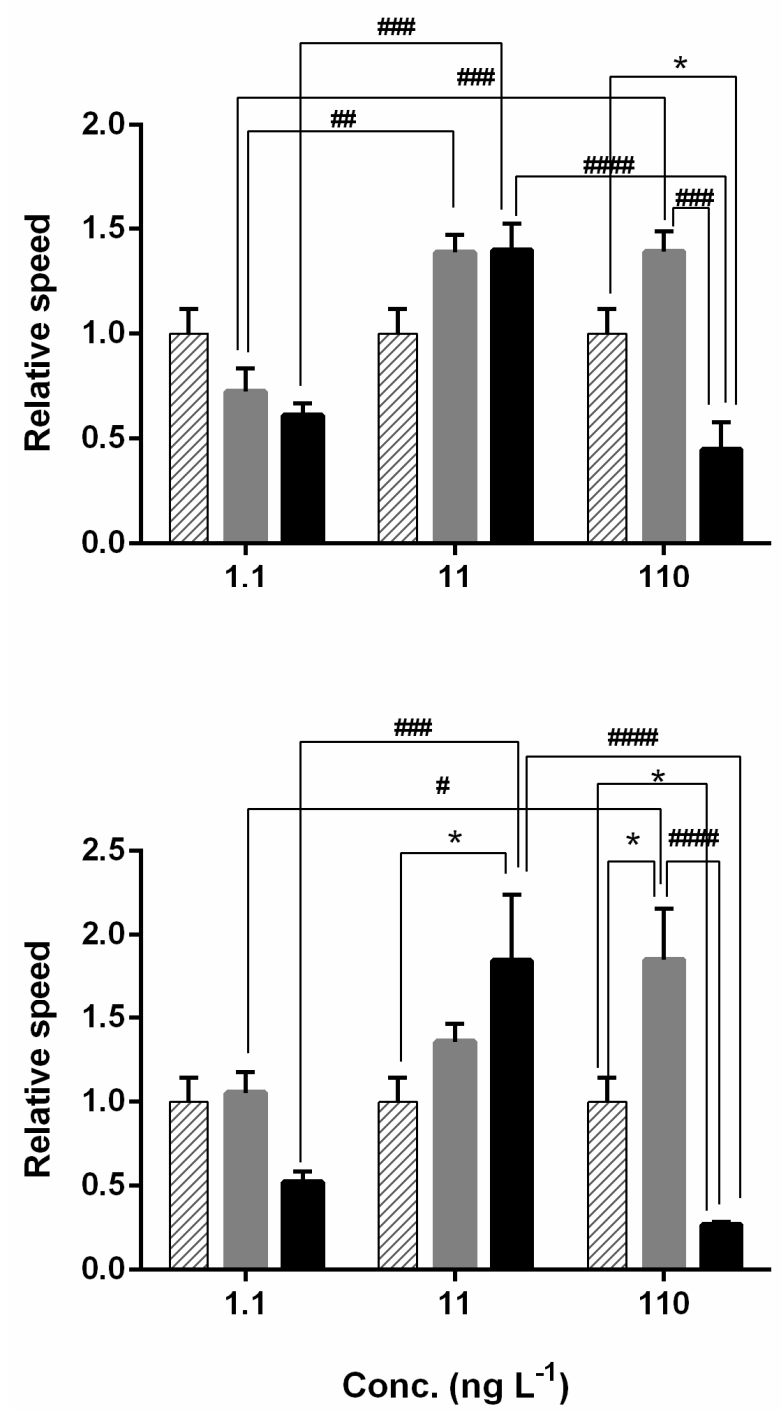

$72 \mathrm{~h}$

(B)

(C)

Figure A4. Relative speed of larvae under combined thermal stress $\left(8\right.$ and $\left.11^{\circ} \mathrm{C}\right)$ and chemical stress with chlorpyrifos $\left(\mathrm{CPF}=1.1,11\right.$, and $110 \mathrm{ng} \mathrm{L}^{-1}$ ) after $24 \mathrm{~h}(\mathbf{A}), 48 \mathrm{~h}(\mathbf{B})$, and $72 \mathrm{~h}(\mathbf{C})$. Asterisks $=$ significant differences from the control group set equal to $1 .{ }^{*} p<0.05 ;{ }^{* * *} p<0.001$. Significant differences among samples exposed to different concentrations ${ }^{\#} p<0.05$; ${ }^{\# \#} p<0.01$; ${ }^{\# \#} p<0.001$; \#\#\#\# $p<0.0001$.

\section{References}

1. EEA (European Environment Agency). Climate Change, Impacts and Vulnerability in Europe 2012. An Indicator-Based Report. EEA Report No 12/2012; European Environment Agency: Copenhagen, Denmark, 2012. Available online: https:/ /www.eea.europa.eu/ publications / climate-impacts-and-vulnerability-2012 (accessed on 5 September 2021).

2. Hageman, K.J.; Hafner, W.D.; Campbell, D.H.; Jaffe, D.A.; Landers, D.H.; Simonich, S.L.M. Variability in pesticide deposition and source contributions to snowpack in Western U.S. National Parks. Environ. Sci. Technol. 2010, 44, 4452-4458. [CrossRef]

3. Villa, S.; Vighi, M.; Finizio, A. Theoretical and experimental evidences of medium range atmospheric transport processes of polycyclic musk fragrances. Sci. Total Environ. 2014, 481, 27-34. [CrossRef]

4. Guzzella, L.; Salerno, F.; Freppaz, M.; Roscioli, C.; Pisanello, F.; Poma, G. POP and PAH contamination in the southern slopes of Mt. Everest (Himalaya, Nepal): Long-range atmospheric transport, glacier shrinkage, or local impact of tourism? Sci. Total Environ. 2016, 544, 382-390. [CrossRef] [PubMed]

5. Steinlin, C.; Bogdal, C.; Luthi, M.P.; Pavlova, P.A.; Schwikowski, M.; Zennegg, M.; Schmid, P.; Scheringer, M.; Hungerbhler, K. A temperate alpine glacier as a reservoir of Polychlorinated Biphenyls: Model results of incorporation, transport, and release. Environ. Sci. Technol. 2016, 50, 5572-5579. [CrossRef]

6. Ferrario, C.; Finizio, A.; Villa, S. Legacy and emerging contaminants in meltwater of three alpine glaciers. Sci. Total Environ. 2017, 574, 350-357. [CrossRef] [PubMed] 
7. Rizzi, C.; Finizio, A.; Maggi, V.; Villa, S. Spatial-temporal analysis of currently used pesticides in Alpine glaciers. Environ. Pollut. 2019, 248, 659-666. [CrossRef] [PubMed]

8. Jeremias, G.; Barbosa, J.; Marques, S.M.; Asselman, J.; Gonalves, F.J.M.; Pereira, J.L. Synthesizing the role of epigenetics in the response and adaptation of species to climate change in freshwater ecosystems. Mol. Ecol. 2016, 27, 2790-2806. [CrossRef]

9. Hotaling, S.; Finn, D.S.; Giersch, J.; Weisrock, D.W.; Jacobsen, D. Climate change and alpine stream biology: Progress, challenges, and opportunities for the future. Biol. Rev. 2017, 92, 2024-2045. [CrossRef]

10. Lencioni, V.; Gobbi, M. Monitoring and conservation of cryophilous biodiversity: Concerns when working with insect populations in vanishing glacial habitats. Insect Conserv. Divers. 2021, 14, 723-729. [CrossRef]

11. Debiasi, D.; Franceschini, A.; Paoli, F.; Lencioni, V. How do macroinvertebrate communities respond to declining glacial influence in the Southern Alps? Limnetica 2022, 41. [CrossRef]

12. Lencioni, V. Glacial influence and stream macroinvertebrate biodiversity under climate change: Lessons from the southern Alps. Sci. Total Environ. 2018, 622-623, 563-575. [CrossRef] [PubMed]

13. Woodward, G.; Perkins, D.M.; Brown, L.E. Climate change and freshwater ecosystems: Impacts across multiple levels of organization. Philos. Trans. R. Soc. Lond. B Biol. Sci. 2010, 365, 2093-2106. [CrossRef] [PubMed]

14. Lencioni, V.; Bernabò, P. Thermal survival limits of young and mature larvae of a cold stenothermal chironomid from the Alps (Diamesinae: Pseudodiamesa branickii [Nowicki, 1873]). Insect Sci. 2017, 24, 314-324. [CrossRef] [PubMed]

15. Lencioni, V.; Bellamoli, F.; Bernabò, P.; Miari, F.; Scotti, A. Response of Diamesa spp. (Diptera: Chironomidae) from Alpine streams to emerging contaminants and pesticides. J. Limnol. 2018, 77, 131-140. [CrossRef]

16. Willming, M.M.; Qin, G.; Maul, J.D. Effects of environmentally realistic daily temperature variation on pesticide toxicity to aquatic invertebrates. Environ. Toxicol. Chem. 2013, 32, 2738-2745. [CrossRef]

17. de Beeck, L.O.; Verheyen, J.; Stoks, R. Integrating both interaction pathways between warming and pesticide exposure on upper thermal tolerance in high- and low- latitude populations of an aquatic insect. Environ. Pollut. 2017, 224, 714-721. [CrossRef]

18. Lencioni, V.; Rodriguez-Prieto, A.; Allegrucci, G. Congruence between molecular and morphological systematics of Alpine non-biting midges (Chironomidae, Diamesinae). Zool. Scr. 2021, 50, 455-472. [CrossRef]

19. Villa, S.; Di Nica, V.; Bellamoli, F.; Pescatore, T.; Ferrario, C.; Finizio, A.; Lencioni, V. Effects on behaviour traits of a treated sewage effluent in Diamesa cinerella and Daphnia magna. J. Limnol. 2018, 77, 121-130.

20. Lencioni, V.; Rossaro, B. Microdistribution of chironomids (Diptera: Chironomidae) in alpine streams: An autoecological perspective. Hydrobiologia 2005, 533, 61-66. [CrossRef]

21. Lencioni, V.; Bernabò, P.; Jousson, O.; Guella, G. Cold adaptive potential of chironomids overwintering in a glacial stream. Physiol. Entomol. 2015, 40, 43-53.

22. Villa, S.; Di Nica, V.; Pescatore, T.; Bellamoli, F.; Miari, F.; Finizio, A.; Lencioni, V. Comparison of the behavioural effects of pharmaceuticals and pesticides on Diamesa zernyi larvae (Chironomidae). Environ. Pollut. 2018, 238, 130-139. [CrossRef]

23. Di Nica, V.; Muñiz Gonzalez, A.B.; Lencioni, V.; Villa, S. Behavioural and biochemical alterations by chlorpyrifos in aquatic insects: An emerging environmental concern for pristine Alpine habitats. Environ. Sci. Pollut. Res. 2020, 27, 30918-30926. [CrossRef]

24. Muñiz-González, A.-B.; Paoli, F.; Martínez-Guitarte, J.-L.; Lencioni, V. Molecular biomarkers as tool for early warning by chlorpyrifos exposure on Alpine chironomids. Environ. Pollut. 2021, 290, 118061. [CrossRef] [PubMed]

25. Gerhardt, A. Aquatic behavioral ecotoxicology prospects and limitations. Hum. Ecol. Risk Assess. 2007, 13, 481-491. [CrossRef]

26. Hellou, J. Behavioural ecotoxicology, an "early warning" signal to assess environmental quality. Environ. Sci. Pollut. Res. 2011, 18, 1-11. [CrossRef] [PubMed]

27. Saaristo, M.; Brodin, T.; Balshine, S.; Bertram, M.G.; Brooks, B.W.; Ehlman, S.M.; McCallum, E.S.; Sih, A.; Sundin, J.; Wong, B.B.M.; et al. Direct and indirect effects of chemical contaminants on the behaviour, ecology and evolution of wildlife. Philos. Trans. $R$. Soc. Lond. B Biol. Sci. 2018, 285, 20181297. [CrossRef] [PubMed]

28. Forbes, V.E.; Calow, P. Is the per capita rate of increase a good measure of population-level effects in ecotoxicology? Environ. Toxicol. Chem. 1999, 18, 1544-1556. [CrossRef]

29. Amiard-Triquet, C. Behavioral disturbances: The missing link between suborganismal and supra-organismal responses to stress? Prospects based on Aquatic Research. Hum. Ecol. Risk Assess. 2009, 15, 87-110. [CrossRef]

30. Duquesne, S.; Kuster, E. Biochemical metabolic and behavioural responses and recovery of Daphnia magna after exposure to an organophosphate. Ecotoxicol. Environ. Saf. 2010, 73, 353-359. [CrossRef]

31. Lencioni, V.; Bernabò, P.; Cesari, M.; Rebecchi, L. Thermal stress induces HSP70 proteins synthesis in larvae of the cold stream non-biting midge Diamesa cinerella Meigen. Arch. Insect Biochem. Physiol. 2013, 83, 1-14. [CrossRef]

32. Rossaro, B.; Lencioni, V. A key to larvae of species belonging to the genus Diamesa from Alps and Apennines (Italy). Eur. J. Environ. Sci. 2015, 5, 62-79. [CrossRef]

33. OECD. Guidance Document on Aqueous_Phase Aquatic Toxicity Testing of Difficult Test Chemicals Series on Testing and Assessment, No. 23, 2nd ed.; ENV/JM/MONO(2000)6/REV1; OECD Publishing: Paris, France, 2018. Available online: http://www.oecd. org/officialdocuments/publicdisplaydocumentpdf/?cote=ENV/JM/MONO(2000)6/REV1\&docLanguage=En (accessed on 5 September 2017).

34. Chapman, P.M.; Riddle, M.J. Toxic effects of contaminants in polar marine environments. Environ. Sci. Technol. 2005, 39, 200A-207A. [PubMed] 
35. Bonzini, S.; Verro, R.; Otto, S.; Lazzaro, L.; Finizio, A.; Zanin, G.; Vighi, M. Experimental validation of a geographical information systems-based procedure for predicting pesticide exposure in surface water. Environ. Sci. Technol. 2006, 40, 7561-7569. [CrossRef] [PubMed]

36. Morselli, M.; Semplice, M.; Villa, S.; Di Guardo, A. Evaluating the temporal variability of POP concentrations in a glacier-fed stream food chain using a combined modelling approach. Sci. Total Environ. 2014, 493, 571-579. [CrossRef]

37. Kenakin, T.P. Pharmacokinetics Reference to a chapter in an edited book. In A Pharmacology Primer. Techniques for More Effective and Strategic Drug Discovery, 4th ed.; Kenakin, T.P., Ed.; Academic Press: Cambridge, MA, USA; Elsevier Inc.: San Diego, CA, USA, 2014; pp. 213-253.

38. Bernabò, P.; Gaglio, M.; Bellamoli, F.; Viero, G.; Lencioni, V. DNA damage and translational response during detoxification from copper exposure in a wild population of Chironomus riparius. Chemosphere 2017, 173, 235-244. [CrossRef]

39. OECD. Test No. 235: Chironomus sp., Acute Immobilisation Test. In OECD Guidelines for the Testing of Chemicals; OECD Publishing: Paris, France, 2011; Section 2.

40. Dudgeon, D.; Arthington, A.H.; Gessner, M.O.; Kawabata, Z.I.; Knowler, D.J.; Leveque, C.; Naiman, R.J.; Prieur-Richard, A.-H.; Soto, D.; Stiassny, M.L.J.; et al. Freshwater biodiversity: Importance, threats, status and conservation challenges. Biol. Rev. 2006, 81, 163-182. [CrossRef]

41. Sabater, S.; Elosegi, A.; Ludwig, R. Multiple Stressors in River Ecosystems: Status, Impacts and Prospects for the Future; Elsevier: Amsterdam, The Netherlands, 2018.

42. Arthington, A.H. Grand Challenges to Support the Freshwater Biodiversity Emergency Recovery Plan. Front. Environ. Sci. 2021, 9, 664313. [CrossRef]

43. Omerod, S.J.; Dobson, M.; Hildrew, A.G.; Townsend, C.R. Multiple stressors in freshwater ecosystems. Freshw. Biol. 2010, 55 (Suppl. S1), 1-4. [CrossRef]

44. Craig, L.S.; Olden, J.D.; Arthington, A.H.; Entrekin, S.; Hawkins, C.P.; Kelly, J.J.; Kennedy, T.A.; Maitland, B.M.; Rosi, E.J.; Roy, A.H.; et al. Meeting the challenge of interacting threats in freshwater ecosystems: A call to scientists and managers. Elementa 2017, 5, 72. [CrossRef]

45. Hasenbein, S.; Poynton, H.; Connon, R.E. Contaminant exposure effects in a changing climate: How multiple stressors can multiply exposure effects in the amphipod Hyalella azteca. Ecotoxicology 2018, 27, 845-859. [CrossRef]

46. Rostgaard, S.; Jacobsen, D. Respiration rate of stream insects measured in situ along a large altitude range. Hydrobiologia 2005, 549, 79-98. [CrossRef]

47. Portner, H.O.; Knust, R. Climate change affects marine fishes through the oxygen limitation of thermal tolerance. Science 2007, 315, 95-97. [CrossRef] [PubMed]

48. Araújo, C.V.M.; Moreira-Santos, M.; Ribeiro, R. Active and passive spatial avoidance by aquatic organisms from environmental stressors: A complementary perspective and a critical review. Environ. Int. 2016, 92-93, 405-415. [CrossRef] [PubMed]

49. Ašmonaité, G.; Boyer, S.; Bresolin de Souza, K.; Wassmur, B.; Sturve, J. Behavioural toxicity assessment of silver ions and nanoparticles on zebrafish using a locomotion profiling approach. Aquat. Toxicol. 2016, 173, 143-153. [CrossRef] [PubMed]

50. Bruno, M.C.; Maiolini, B.; Carolli, M.; Silveri, L. Impact of hydropeaking on hyporheic invertebrates in an Alpine stream (Trentino, Italy). Ann. Limnol. Int. J. Limnol. 2009, 45, 157-170. [CrossRef]

51. Lencioni, V.; Spitale, D. Diversity and distribution of benthic and hyporheic fauna in different stream types on an alpine glacial floodplain. Hydrobiologia 2015, 751, 73-87. [CrossRef]

52. Calow, P. Physiological costs of combating chemical toxicants: Ecological implications. Comp. Biochem. Physiol. Part C Comp. Pharmacol. Toxicol. 1991, 100, 3-6. [CrossRef]

53. Rubach, M.N.; Crum, S.J.H.; Van den Brink, P.J. Variability in the dynamics of mortality and immobility responses of freshwater arthropods exposed to chlorpyrifos. Arch. Environ. Contam. Toxicol. 2011, 60, 708-721. [CrossRef]

54. Augusiak, J.; Van den Brink, P.J. The influence of insecticide exposure and environmental stimuli on the movement behaviour and dispersal of a freshwater isopod. Ecotoxicology 2016, 25, 1338-1352. [CrossRef]

55. Scherer, C.; Seeland, A.; Oehlmann, J.; Müller, R. Interactive effects of xenobiotic, abiotic and biotic stressors on Daphnia pulex results from a multiple stressor experiment with a fractional multifactorial design. Aquat. Toxicol. 2013, 138-139, 105-115. [CrossRef]

56. Andrade, T.S.; Henriques, J.F.; Almeida, A.R.; Machado, A.L.; Koba, O.; Giang, P.T.; Soares, A.M.; Domingues, I. Carbendazim exposure induces developmental, biochemical and behavioural disturbance in zebrafish embryos. Aquat. Toxicol. 2016, 170, 390-399. [CrossRef]

57. Lydy, M.J.; Belden, J.B.; Ternes, M.A. Effects of temperature on the toxicity of m-parathion, chlorpyrifos, and pentachlorobenzene to Chironomus tentans. Arch. Environ. Contam. Toxicol. 1999, 37, 542-547. [CrossRef]

58. Harwood, A.D.; You, J.; Lydy, M.J. Temperature as a toxicity identification evaluation tool for pyrethroid insecticides: Toxicokinetic confirmation. Environ. Toxicol. Chem. 2009, 28, 1051-1058. [CrossRef]

59. Van, K.D.; Janssens, L.; Debecker, S.; Stoks, R. Warming increases chlorpyrifos effects on predator but not anti-predator behaviours. Aquat. Toxicol. 2014, 152, 215-221.

60. Buchwalter, D.B.; Jenkins, J.J.; Curtis, L.R. Temperature influences on water permeability and chlorpyrifos uptake in aquatic insects with differing respiratory strategies. Environ. Toxicol. Chem. 2003, 22, 2806-2812. [CrossRef] [PubMed]

61. Chapman, P.M. Toxicity delayed in cold freshwaters? J. Great Lakes 2016, 42, 286-289. [CrossRef] 
62. Noyes, P.D.; Lema, S.C. Forecasting the impacts of chemical pollution and climate change interactions on the health of wildlife. Curr. Zool. 2015, 61, 669-689. [CrossRef]

63. Mohammed, S.; Lamoree, M.; Ansa-Asare, O.D.; de Boer, J. Review of the analysis of insecticide residues and their levels in different matrices in Ghana. Ecotoxicol. Environ. Saf. 2019, 171, 361-372. [CrossRef] [PubMed]

64. Vecchiato, M.; Gambaro, A.; Kehrwald, N.M.; Ginot, P.; Kutuzov, S.; Mikhalenko, V.; Barbante, C. The Great Acceleration of fragrances and PAHs archived in an ice core from Elbrus, Caucasus. Sci. Rep. 2020, 10, 10661. [CrossRef]

65. Wang, P.; Ng, Q.X.; Zhang, H.; Zhang, B.; Ong, C.N.; He, Y. Metabolite changes behind faster growth and less reproduction of Daphnia similis exposed to low-dose silver nanoparticles. Ecotoxicol. Environ. Saf. 2018, 163, 266-273. [CrossRef] 